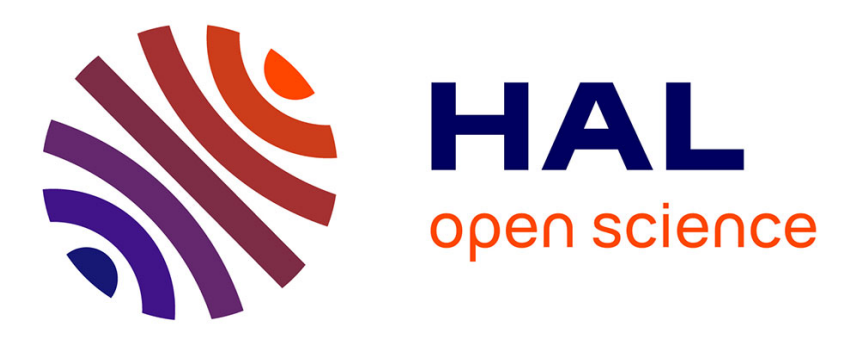

\title{
First description of clinical isolates carrying both and genes in Portugal
}

Sónia Ferreira, Mark Toleman, Elmano Ramalheira, Gabriela J. da Silva, Timothy Walsh, Sónia Mendo

\section{To cite this version:}

Sónia Ferreira, Mark Toleman, Elmano Ramalheira, Gabriela J. da Silva, Timothy Walsh, et al.. First description of clinical isolates carrying both and genes in Portugal. International Journal of Antimicrobial Agents, 2010, 35 (6), pp.584. 10.1016/j.ijantimicag.2010.01.019 . hal-00585820

\section{HAL Id: hal-00585820 https://hal.science/hal-00585820}

Submitted on 14 Apr 2011

HAL is a multi-disciplinary open access archive for the deposit and dissemination of scientific research documents, whether they are published or not. The documents may come from teaching and research institutions in France or abroad, or from public or private research centers.
L'archive ouverte pluridisciplinaire HAL, est destinée au dépôt et à la diffusion de documents scientifiques de niveau recherche, publiés ou non, émanant des établissements d'enseignement et de recherche français ou étrangers, des laboratoires publics ou privés. 


\section{Accepted Manuscript}

Title: First description of Klebsiella pneumoniae clinical isolates carrying both $q n r A$ and $q n r B$ genes in Portugal ${ }^{1}$

Authors: Sónia Ferreira, Mark Toleman, Elmano Ramalheira, Gabriela J. Da Silva, Timothy Walsh, Sónia Mendo

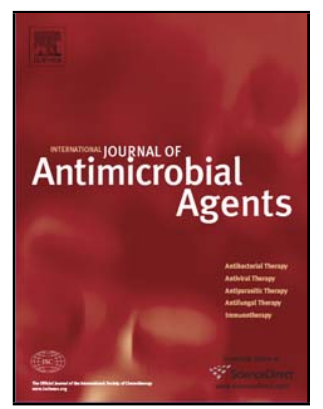

PII:

S0924-8579(10)00064-6

DOI: doi:10.1016/j.ijantimicag.2010.01.019

Reference: ANTAGE 3243

To appear in: International Journal of Antimicrobial Agents

Received date: $\quad$ 12-11-2009

Revised date: $\quad 17-12-2009$

Accepted date: $\quad 14-1-2010$

Please cite this article as: Ferreira S, Toleman M, Ramalheira E, Da Silva GJ, Walsh T, Mendo S, First description of Klebsiella pneumoniae clinical isolates carrying both $q n r A$ and $q n r B$ genes in Portugal ${ }^{1}$, International Journal of Antimicrobial Agents (2008), doi:10.1016/j.ijantimicag.2010.01.019

This is a PDF file of an unedited manuscript that has been accepted for publication. As a service to our customers we are providing this early version of the manuscript. The manuscript will undergo copyediting, typesetting, and review of the resulting proof before it is published in its final form. Please note that during the production process errors may be discovered which could affect the content, and all legal disclaimers that apply to the journal pertain. 


\section{First description of Klebsiella pneumoniae clinical isolates} carrying both qnrA and qnrB genes in Portugal *

Sónia Ferreira ${ }^{\mathrm{a}, \mathrm{b}, \mathrm{c}}$, Mark Toleman ${ }^{\mathrm{b}}$, Elmano Ramalheira ${ }^{\mathrm{c}}$, Gabriela J. Da Silva $^{\mathrm{d}}$, Timothy Walsh ${ }^{\mathrm{b}}$, Sónia Mendo ${ }^{\mathrm{a}, *}$

a University of Aveiro, Department of Biology, CESAM, 3810-193 Aveiro, Portugal

b School of Medicine, Department of Medical Microbiology, Cardiff University, Heath Park, Cardiff CF14 4XN, UK

${ }^{c}$ Hospital Infante D. Pedro EPE, 3810 Aveiro, Portugal

${ }^{\mathrm{d}}$ Center of Pharmaceutical Sciences, University of Coimbra, Health Sciences Campus, Faculty of Pharmacy, Department of Microbiology, Azinhaga de Santa Comba, 3000-548 Coimbra, Portugal

\section{ARTICLE INFO}

Article history:

Received 12 November 2009

Accepted 14 January 2010

Keywords:

qnr genes

Quinolone resistance

Klebsiella pneumoniae 
${ }^{*}$ Corresponding author. Present address: CESAM \& Departamento de Biologia, Universidade de Aveiro, Campus de Santiago, 3810-193 Aveiro, Portugal. Tel.: +351234370 970; fax: +351234372587.

E-mail address: smendo@ua.pt (S. Mendo).

* This work was presented in part at the 48th Interscience Conference on Antimicrobial Agents and Chemotherapy (ICAAC) and the 46th Annual Meeting of the Infectious Diseases Society of America (IDSA), 25-28 October 2008, Washington DC. 


\section{ABSTRACT}

In the present study, 21 multidrug-resistant Klebsiella pneumoniae isolates were recovered from patients hospitalised in the Intensive Care Unit of Hospital Infante D. Pedro in Aveiro, Portugal. Fifteen isolates carried qnr genes. Four strains harboured the quinolone resistance genes $q n r A$ and $q n r B$, both located on a large plasmid in two strains (KP4 and KP10) and on different plasmids in two strains (KP5 and KP6). These findings indicate an extremely high prevalence of qnr genes associated with various mobile elements such as ISCR1 and class 1 integrons. 


\section{Introduction}

Plasmid-mediated quinolone resistance encoded by $q n r A$, qnrB or qnrS genes has been reported worldwide [1,2]. Qnr proteins are members of the pentapeptide repeat protein family that protect topoisomerases and thereby reduce their susceptibility to fluoroquinolones [1,3]. qnrA was the first $q n r$ gene described in a Klebsiella pneumoniae in 1998 by Martínez-Martínez et al. [4]. Subsequently, it has been shown to be widely spread worldwide as part of a complex sul1-type integron containing ISCR1 [1,5]. qnrB and qnrS have also been reported in many countries from Europe, Asia and the USA [1]. Dissemination of plasmids carrying these genes can potentiate the rapid development of higher-level quinolone resistance in bacterial strains currently classified as susceptible [6]. Moreover, transferrable qnr genes are usually carried by conjugative plasmids (50-180 kb) that often encode extendedspectrum $\beta$-lactamases (ESBLs) or AmpC-type $\beta$-lactamases [7]. In fact, epidemiological studies of the distribution of qnr determinants show that qnrpositive strains frequently express ESBLs [8]. Here we report the presence of qnr genes in quinolone-resistant $K$. pneumoniae and investigate their association with different $\beta$-lactamases.

\section{Material and methods}

\subsection{Klebsiella pneumoniae clinical isolates}

Twenty-one K. pneumoniae were isolated from various biological products, including urine, wound swabs, respiratory secretions, blood and sterile body 
fluids, collected from patients in the Intensive Care Unit of Hospital Infante D. Pedro (Aveiro, Portugal). Species identification was performed using the VITEK 2 system (bioMérieux, Marcy l'Etoile, France). The population analysed was non-repetitive and only a single isolate per patient was included in the study.

\subsection{Drug susceptibility testing}

Susceptibility testing was performed according to the guidelines of the Clinical and Laboratory Standard Institute [9]. ESBL production was confirmed by Etest with cefotaxime/cefotaxime + clavulanic acid, ceftazidime/ceftazidime + clavulanic acid and cefepime/cefepime + clavulanic acid strips, according to manufacturer's instructions (AB BIODISK, Solna, Sweden).

\subsection{Hybridisation assays}

Resolution of S1-digested genomic DNA of $K$. pneumoniae isolates was performed with a CHEF-DRIII system (Bio-Rad, Hemel Hempstead, UK). Chromosomal and plasmid DNA were separated by electrophoresis in a $1 \%$ agarose gel in $0.5 \times$ TBE buffer $(\mathrm{pH} 8.0)$ at $200 \mathrm{~V}$ and $14{ }^{\circ} \mathrm{C}$ for $20 \mathrm{~h}$, with the pulse time ramped from $5 \mathrm{~s}$ to $45 \mathrm{~s}$. The resulting pulsed-field gel electrophoresis (PFGE) gel was used to assess the qnr gene location, which was determined by DNA-DNA hybridisation using a radiolabelled probe consisting of polymerase chain reaction (PCR)-generated qnrA and qnrB genes. 


\subsection{Polymerase chain reaction and DNA sequencing}

PCR detection of class 1 integrons was performed as previously described [10]. The presence of qnr genes was detected by PCR using the primers described by Wu et al. [11]. All isolates were screened by PCR for the presence of SHV, CTX-M, TEM and OXA $\beta$-lactamases as well as AmpC groups (DHA, MOX, FOX, CMY and ACC) [12]. Nucleotide sequences of PCR products were determined and compared with other sequences deposited in the EMBL GenBank.

\subsection{Conjugation assays}

Conjugation assays were performed with Escherichia coli J53 Azi (azideresistant) as recipient and KP4, KP5, KP6 and KP10 as donors. Strains were routinely grown in Luria-Bertani broth. Culture plates contained tryptic soy agar or Mueller-Hinton (MH) agar (Becton Dickinson and Co., Sparks, MD). Selective media plates (MH agar) contained $100 \mu \mathrm{g} / \mathrm{mL}$ sodium azide and one of the following antibiotics: ciprofloxacin $(0.125 \mu \mathrm{g} / \mathrm{mL})$; sulfamethoxazole (100 $\mu \mathrm{g} / \mathrm{mL})$; or chloramphenicol $(40 \mu \mathrm{g} / \mathrm{mL})$.

\section{Results and discussion}

All 21 isolates were resistant to nalidixic acid [minimum inhibitory concentration (MIC) $\geq 32 \mu \mathrm{g} / \mathrm{mL}$ )] and ciprofloxacin (MIC $\geq 4 \mu \mathrm{g} / \mathrm{mL}$ ). Nineteen isolates were intermediate resistant $(8 \mu \mathrm{g} / \mathrm{mL})$ and two were resistant $(\geq 16$ $\mu \mathrm{g} / \mathrm{mL}$ ) to norfloxacin. Six strains were identified as being ESBL-producers. 
Fifteen of the twenty-one isolates tested positive for the presence of qnr genes (Table 1). Twelve carried qnrA1, which in eight isolates was found downstream of In 37 and ISCR1 that codes for a transposase and provides the promoter sequences for high-level expression of the plasmid-mediated $q n r A$ gene in Enterobacteriaceae. All isolates co-harbouring $q n r A, \operatorname{aac}\left(6^{\prime}\right)-\mathrm{lb}-\mathrm{cr}$ and bla XX-30 also harboured ISCR1 and a class 1 integron. Three isolates carried $q n r B$ alone. The qnrS gene was not detected. Previous reports describe the expression of qnrA and qnrS [3], and the co-existence of qnrB4 and qnrS in the same K. pneumoniae isolate in two different plasmids has also been reported [2]. However, here we report four isolates positive for both qnrA and qnrB simultaneously (KP4, KP5, KP6 and KP10). Digestion with S1 revealed the presence of plasmids ranging in size from $50 \mathrm{~kb}$ to $450 \mathrm{~kb}$ in the strains possessing both genes (data not shown). S1-restricted plasmids were hybridised with labelled $q n r A-$ and $q n r B$-specific probes revealing that both genes are plasmid-encoded and that qnrA1 and qnrB4 are located on the same plasmid in two of the strains (KP4 and KP10) and on different plasmids in two strain (KP5 and KP6) (data not shown). The qnrA1 gene was found on a $450 \mathrm{~kb}$ plasmid in strains KP4, KP5, KP6 and KP10. The qnrB4 gene was located on the same $450 \mathrm{~kb}$ plasmid in two of the strains (KP4 and KP10) and on a $75 \mathrm{~kb}$ plasmid in strains KP5 and KP6. This is the first report of the presence of both qnrA1 and qnrB4 on the same plasmid. Conjugation was attempted using E. coli J53 $\mathrm{Azi}^{\mathrm{r}}$ as recipient, however none of the qnr genes could be transferred under the different experimental laboratory conditions tested. $\beta$-Lactamase screening in all isolates revealed that bla in $38 \%$ of the isolates and blasHv in $85.7 \%$. blaoxA was found in $38 \%$ of the 
isolates and was found to be part of the In 37 array in all of them. Interestingly, although a genetic linkage between b/a CTX-M and $\operatorname{aac}\left(6^{\prime}\right)-I b-c r$ has been reported previously [13-15], bla cephalosporin-resistant isolates harboured qnr genes, thus suggesting a linkage between the presence of qnr and resistance to cephalosporins as previously reported $[1,3]$. Strains KP4 and KP5, although negative for blacTX-M, harboured $q n r A$, $q n r B$ and bla $a_{\mathrm{DHA}-1}$ encoding a plasmidic AmpC-type $\beta$ lactamase that confers resistance to cephamycins and extended-spectrum cephalosporins, explaining the resistance to cephalosporins exhibited by these isolates. Moreover, int/1 was detected in $80 \%$ of the isolates, and $38 \%$ carried more than one integron. A total of 18 gene cassettes occurring in three different cassette arrays were identified, with the variants of aadA and dfrA genes being most frequent. The complex integron In $37\left[\operatorname{aac}\left(6^{\prime}\right)-\mathrm{lb}-\mathrm{cr}\right.$, blaOXA30, catB3, arr-3]:ISCR1:qnrA1 was found in eight isolates; this structure has been previously described in an E. coli isolate from China (accession no. AY259086). Our results showed a high association between aac(6')-Ib-cr, blaoxA-30, class 1 integron, ISCR1 and qnrA, as previously reported [15], suggesting the dissemination of this structure worldwide. Also, most of the qnr-positive isolates carried a bla gene encoding an ESBL or an ampC gene coding DHA-1, reinforcing once again a possible relationship between qnr genes and broad spectrum $\beta$-lactamases $[1,16]$. These findings indicate an extremely high prevalence of qnr genes associated with various mobile elements such as ISCR1 and class 1 integrons. Moreover, the role of coexistence of both qnrA and qnrB for the strain still needs to be clarified, 
however it can act as a reservoir that will further disseminate these genes to sensitive bacteria.

\section{Acknowledgment}

The authors thank the Department of Medical Microbiology of Hospital Infante D. Pedro EPE (Aveiro, Portugal) for the strains.

\section{Funding}

SF was funded by a fellowship (SFRH/BDE/15573/2005) from Fundação para a Ciência e a Tecnologia de Portugal and by Hospital Infante D. Pedro. EPE (Aveiro, Portugal).

\section{Competing interests}

None declared.

\section{Ethical approval}

Not required 


\section{References}

[1] Nordmann P, Poirel L. Emergence of plasmid-mediated resistance to quinolones in Enterobacteriaceae. J Antimicrob Chemother 2005;56:4639.

[2] Wang A, Yang Y, Lu Q, Wang Y, Chen Y, Deng L, et al. Occurrence of qnr-positive clinical isolates in Klebsiella pneumoniae producing ESBL or AmpC-type $\beta$-lactamase from five pediatric hospitals in China. FEMS Microbiol Lett 2008;283:112-6.

[3] Cavaco LM, Hansen DS, Friis-Moller A, Aarestrup FM, Hasman H, Frimodt-Moller N. First detection of plasmid-mediated quinolone resistance (qnrA and qnrS) in Escherichia coli strains isolated from humans in Scandinavia. J Antimicrob Chemother 2007;59:804-5.

[4] Martínez-Martínez L, Pascual A, Jacoby GA. Quinolone resistance from a transferable plasmid. Lancet 1998;351:797-9.

[5] Park Y-J, Yu JK, Lee S, Oh E-J, Woo G-J. Prevalence and diversity of qnr alleles in AmpC-producing Enterobacter cloacae, Enterobacter aerogenes, Citrobacter freundii and Serratia marcescens: a multicentre study from Korea. J Antimicrob Chemother 2007;60:868-71.

[6] Robicsek A, Sahm DF, Strahilevitz J, Jacoby GA, Hooper DC. Broader distribution of plasmid-mediated quinolone resistance in the United States. Antimicrob Agents Chemother 2005;49:3001-3.

[7] Lascols C, Podglajen I, Verdet C, Gautier V, Gutmann L, Soussy CJ, et al. A plasmid-borne Shewanella algae gene, qnrA3, and its possible transfer in vivo between Kluyvera ascorbata and Klebsiella pneumoniae. J Bacteriol 2008;190:5217-23. 
[8] Garnier F, Raked N, Gassama A, Denis F, Ploy M-C. Genetic environment of quinolone resistance gene qnrB2 in a complex sul1-type integron in the newly described Salmonella enterica serovar Keurmassar. Antimicrob Agents Chemother 2006;50:3200-2.

[9] Clinical and Laboratory Standards Institute. Performance standards for antimicrobial susceptibility testing. Seventeenth informational supplement. Document M100-S17. Wayne, PA: CLSI; 2007.

[10] Barlow RS, Pemberton JM, Desmarchelier PM, Gobius KS. Isolation and characterization of integron-containing bacteria without antibiotic selection. Antimicrob Agents Chemother 2004;48:838-42.

[11] Wu JJ, Ko WC, Tsai SH, Yan JJ. Prevalence of plasmid-mediated quinolone resistance determinants QnrA, QnrB, and QnrS among clinical isolates of Enterobacter cloacae in a Taiwanese hospital. Antimicrob Agents Chemother 2007;51:1223-7.

[12] Henriques IS, Fonseca F, Alves A, Saavedra MJ, Correia A. Occurrence and diversity of integrons and $\beta$-lactamase genes among ampicillin-resistant isolates from estuarine waters. Res Microbiol $2006 ; 157: 938-47$.

[13] Machado E, Coque TM, Cantón R, Baquero F, Sousa JC, Peixe L; Portuguese Resistance Study Group. Dissemination in Portugal of CTX-M15-, OXA-1-, and TEM-1-producing Enterobacteriaceae strains containing the $\operatorname{aac}\left(6^{\prime}\right)-$ Ib-cr gene, which encodes an aminoglycoside- and fluoroquinolone-modifying enzyme. Antimicrob Agents Chemother 2006;50:3220-1. 
[14] Cordeiro NF, Robino L, Medina J, Seija V, Bado I, García V, et al. Ciprofloxacin-resistant enterobacteria harboring the aac(6')-lb-cr variant isolated from feces of inpatients in an intensive care unit in Uruguay. Antimicrob Agents Chemother 2008;52:806-7.

[15] Kim S-Y, Park Y-J, Yu JK, Kim YS, Han K. Prevalence and characteristics of aac(6')-Ib-cr in AmpC-producing Enterobacter cloacae, Citrobacter freundii, and Serratia marcescens: a multicenter study from Korea. Diagn Microbiol Infect Dis 2009;63:314-8.

[16] Pai H, Seo M-R, Choi TY. Association of $q n r B$ determinants and production of extended-spectrum $\beta$-lactamases or plasmid-mediated AmpC $\beta$-lactamases in clinical isolates of Klebsiella pneumoniae. Antimicrob Agents Chemother 2007;51:366-8. 


\section{Table 1}

Characteristics of $q n r A-, q n r B-$ and $q n r A / q n r B$-positive Klebsiella pneumoniae strains

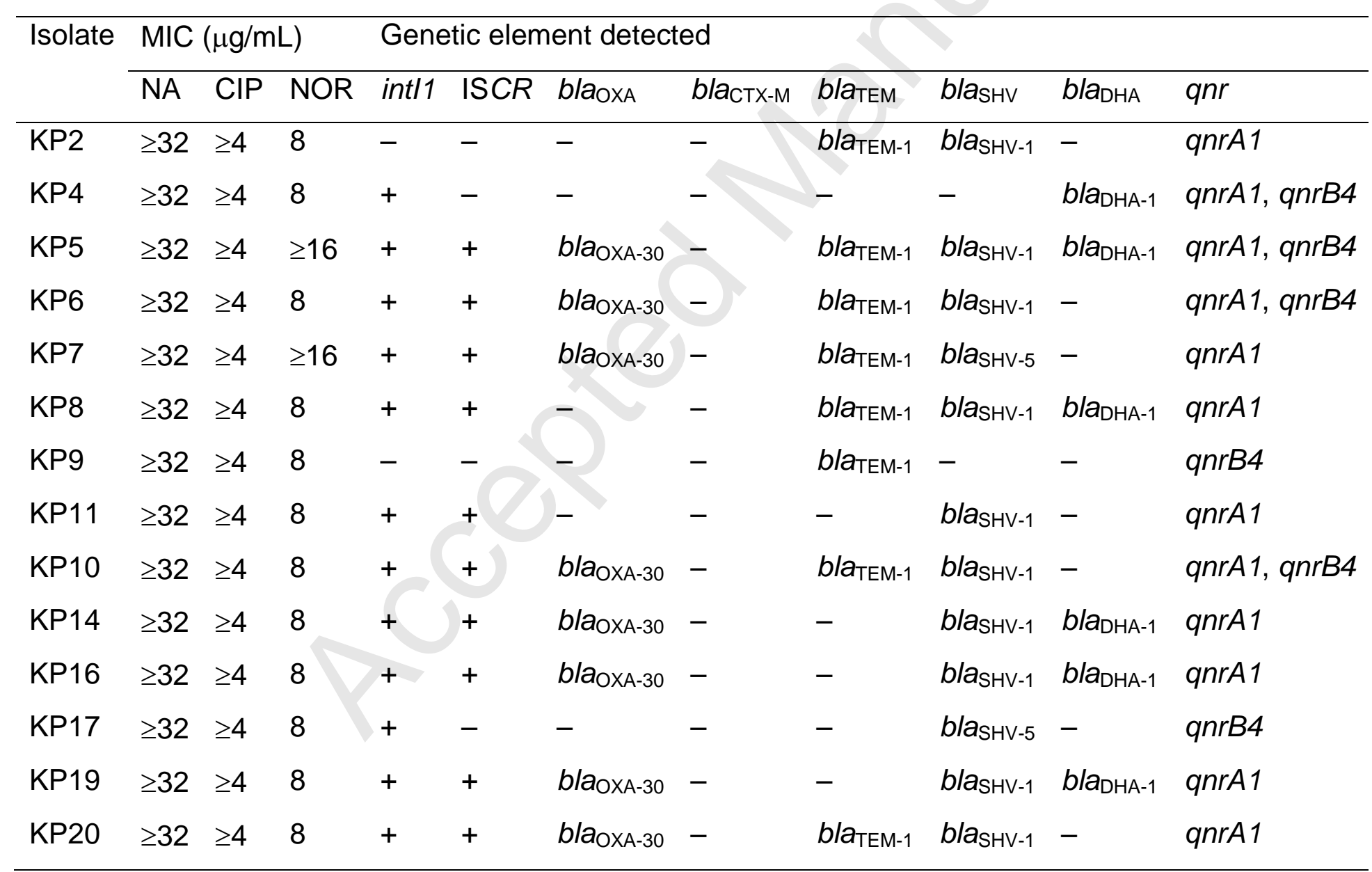




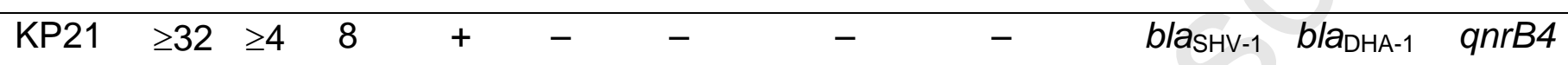

MIC, minimum inhibitory concentration; NA, nalidixic acid; CIP, ciprofloxacin; NOR, norfloxacin; -, negative for the presence of the screened gene; +, positive for the presence of the screened gene. 